\title{
THE UNIVERSITY AS A PHILOSOPHICAL PROBLEM
}

\author{
EMIL VIŠŇOVSKÝ
}

\begin{abstract}
The paper provides a philosophical insight into the contemporary critical trends in the university life, and an outline of possible solutions based on the historical overview of an idea of university. The particular section is devoted to the depiction of situation in Slovakia. The author suggests that the creative reconstruction of academic practices is the key to the future of university.
\end{abstract}

Key words: university; academic practice; globalisation; neoliberalism; Slovakia; creativity

\section{Introduction}

The general consensus is that academic-universities and colleges-around the world are undergoing unprecedented change. Even in Europe, the reforms of recent decades have resulted in its modern universities no longer retaining their original character, whether that be the "Humboldtian" or "Napoleonic" idea of the university, or "Newman's". The extent to which universities are changing in structure and design, in management and administration, and in their social mission and academic working conditions is such that we can state with almost complete certainty that the university as we once knew it no longer exists.

And yet, there is no broad consensus on the actual direction of these changes, nor indeed on what that direction should be. In this uneasy world, there are few who would predict where our academic institutions are headed. Many theorists unhesitatingly pick up on the claims made some time ago by the American literary scholar B. Readings (1997) in his book about "universities in ruins", and accordingly they talk of "corruption" (Washburn, 2005), or of the "lost soul" (Schrecker, 2010) of the university or of an "attack" to be met with "resistance" (Bailey \& Freedman, 2011). Some have once again begun questioning the meaning and the point of the university_-"What are universities for?" (Collini, 2012)—while others are quick to remind us "what college was, is and should be" (Delbanco, 2012), and to highlight that it is "not for profit" (Nussbaum, 2010). But alongside all these, there is clearly a majority who are attempting to view the situation realistically, as an opportunity to "transform" or even "renew" and "restore" the original idea of the university (Barnett, 2010; Graham, 2008). While yet others proffer new versions, such as the "postmodern university" (Smith \& Webster, 1997), the "virtual university" (Robins \& Webster, 2002) or

DE GRUYTER 
the "ecological university" (Barnett, 2010). The idea of the "multiversity" (Kerr, 2001) also appeared some time ago.

The current situation in the "academic sphere" is sufficiently complex to require an exceptional dose of creative intelligence and cooperation at both the global and local levels. In the social context, the determining factors have been theoretically identified more than once. They are, above all, globalisation and crisis, neoliberalism and academic capitalism, corporatisation and managerialism, marketisation and commodification, economisation and bureaucratisation. The consequences of these trends are equally well known and include the loss of academic autonomy, the endangerment of academic freedom, a change in the nature of academic work and the destabilisation of the academic identity of university and research staff (Liessmann, 2006). But the most important, and as yet unresolved, questions are clearly these: What kind of university do we want? And who should decide: the academics themselves, or the public, the market or the state, or even all of us together? And coordinated in what way?

The battle over public resources and for education funding is drawing ever more social factors and actors into the "game", creating such unprecedented "pressures" on university life that there can be no mention of mythical "ivory towers" today. In our socalled "educated" or "knowledge" society, the university is taking centre stage in political and economic events, whether academic staff wish it or not. The context of their work has undergone major change, the consequences of which are not necessarily positive, since the change in context brings with it the fear that the nature of the work will be transformed, and that is much more serious. After all, if we want academic work to generate what it has always generated in developed countries - that is, quality teaching and research outcomes at universities - then we clearly need to maintain its raison d'être and core. Academic work has always had its special features, without which it would cease to be what it has always been, and without which it would not have the potential to bear the fruit society demands of it. ${ }^{1}$ This claim is by no means against any positive changes in the character of intellectual/ academic work, but the issue is very complex.

\footnotetext{
1 There is no doubt the current academic situation in Slovakia (as in other Central and Eastern European countries) is yet more complicated because of other factors such as the political and sociocultural heritage, the economic and social transition, intellectual chaos and moral uncertainty, etc. There has yet to be a systematic scientific analysis of academic culture and university education in Slovakia, unlike in advanced countries where there has long been institutional research in this area. The debate of the last 25 years on the academic sphere in Slovakia has been marked by campaigning, selfinterest, a lack of conception, political opportunism and pressures, as well as instability and external interventions that have taken traditional academic freedom and autonomy to their limits. The media "refrain" on the "poor quality" of our higher education institutions is endless and has on more than one occasion been deliberately exploitative, drawing on the fact that no Slovak higher education institution appears in the first or even fifth league of the world's universities (if we count each "league" as having 100 teams), that the percentage of important research findings per academic is below that at globally renowned universities, and that Slovak universities perform badly on other standard international indicators of the value of universities.
} 


\section{Idea of the university: a brief excursion into the philosophical concept of the university}

The basic question, which cannot be answered without turning to philosophy, is of course: "What is the university?"; in other words, what constitutes its essence? The answers to this question - the idea of the university as the highest educational institution - lie in the ideas of important philosophers from Plato to the present. The idea of the university, like the original medieval notion of a "community of teachers and scholars" (universitas magistrorum et scholarium), is rooted in the ancient idea of the academy. Plato's academy (founded around 387-385 AD) was the first embodiment of this idea and, besides being a community of people who met to learn and study, it was an inalienable place of quiet, concentrated study and learning, discussion and teaching, discovery and reflection. ${ }^{2}$ It is where the roots of the traditional idea of academic freedom and autonomy lie, reflected in the nature of academic work, later described by J. G. Fichte as involving "emancipation from the constraints" and "from all supervision," the "liberty to do all that is right and becoming by their own free determination," because the scholar must have a "profound morality" and "fine delicacy of feeling", for he alone "must be a law to himself and hold himself to its fulfilment" (Fichte, 1806/1873, pp. 185-193). This is crucial to the authentic motivation for academic work, which can only come from "within" not from "without"; that is, from the academic (the sage, the scholar, the learned one) who works for the sake of learning and study, research and teaching, and for the results it brings, not for a reward or sanctions imposed from outside (in the shape of fame, power or money, or even to have them confiscated; nor to "win/ lose" the academic contest, do well in the rankings or "performance standards", or obtain qualifications, credits or "points", etc.). ${ }^{3}$

This notion of authentic academic identity was bolstered further by the ideas of Roman Stoics ${ }^{4}$, medieval philosophers ${ }^{5}$ and renaissance humanists. ${ }^{6}$ Thus the project of the university acquired a fundamental humanistic dimension as a project in the first instance for nurturing educated (cultivated) individuals, and this was then continued by Enlightenment thinkers. ${ }^{7}$

\footnotetext{
2 This place in Athens was an "Academic Grove" of plane trees and olive trees, named after the fabled hero Academa (Hecademos), later blessed as Athena the goddess of wisdom; it was a shrine, protected from military incursion for centuries (desecrated by the Roman general Sulla in 86 AD).

3 In this sense and before Fichte's time, the scholar distinction was made, for example, by Friedrich Schiller, who distinguished between those for whom knowing the truth was key and those for whom the reward was important (Was heißt und zu welchem Ende studiert man Universalgeschichte? Jena: Akademisches Buchhandlung, 1979). Basically, these were the Aristotelean intellectual and moral virtues, analysed in the contemporary era by, among others, A. Macintyre (2009).

4 Cicero (the idea that humanity and humanism cultivate individuals), Seneca ("man is a god to man"), Marcus Aurelius (a "catalogue" of human qualities: modesty, courage, self-control, tolerance).

5 St. Augustin (the notion of the teacher), St. Thomas Aquinas (the idea of perennialism as teaching the material, universal and essential).

6 They reformulated the Ancient trivium (grammar, rhetoric, logic) as the humanities (grammar, rhetoric, poetry, history and moral philosophy).

7 Locke (the great potential of education), Rousseau (education as a barrier against the harmful influences of society), Voltaire (idea of human dignity), Kant (idea of the autonomous faculty).
} 
It was in this spirit that the model of the modern university was conceived by Wilhelm von Humboldt, founder of Berlin University (1810), where the first rector was none other than J. G. Fichte. For Humboldt (2010), the essence of the university was derived from two principles: (1) a community of scholars dedicated to intellectual work who would (2) perform this work as an end in itself independent of its practical use or prospects. Key to this was that teachers and students engaged in scientific learning together, and that teaching was a natural part of this process (not the other way round). The mission of the Humboldtian university was cultural—it was about the formation (Bildung) of the citizen of a nation-state as an educated, cultured individual, and posited the university as the central cultural institution in modern society. This basic model served as the inspiration for building universities in Europe and in the West for the next 200 years.

In the mid-nineteenth century the work of Humboldt would come to inform the thinking of an important Irish philosopher and theologian, Cardinal John Henry Newman, founder of the Catholic University in Dublin, whose ideas had most influence (albeit selectively) on the Anglo-American model of the university. ${ }^{8} \mathrm{He}$ considered the university to be a "temple" of the highest knowledge and science, which should be protected and developed; however, its key activity was not study but education (teaching). In the introduction to his lectures published in his well-known book, The Idea of a University (1852, ix), he states: A university is "a place of teaching universal knowledge. This implies its object is... the diffusion and extension of knowledge rather than advancement. If its object were scientific and philosophical discovery, I do not see why a University should have students...". The university's mission was to develop intellectual culture and to shape its students' intellects, not their practical skills for their future vocations (Newman, 1852, pp. 125-126).

The problem of the university was still a concern to some philosophers in the twentieth century. K. Jaspers (1923/1946) spoke out against the destruction of university life that fascism represented. He thought every authentic university should fulfill three goals together: 1. academic education, 2. scientific research and 3. cultural life. In a similar context, Ortega y Gasset (1930/1997) articulated his own vision of a cosmopolitan university (in his lectures at Madrid University), based on the idea of a "general culture", cultivated by the university as part of its integral mission. Besides the traditional goals of the university, he considered the societal and political dimensions to be important in shaping educated political individuals, capable of helping create a good society and government, social justice and responsibility. T. W. Adorno (1959/1998) expressed deep dissatisfaction at the seeming destiny of the university (and education and culture in general) on observing the midtwentieth century tendency for instrumental rationalisation, economisation, fragmentation, and so on, in academic life, which he considered to be a retrograde slip into "half-education". These tendencies were part of a general crisis of modernity and academic culture, described in stronger terms by postmodernist philosophers, such as J.-F. Lyotard (1979/1984), who spoke of the "internal erosion of the principles of legitimacy" in education, knowledge and

\footnotetext{
8 In the USA, Abraham Flexner was a radical follower of Newman who summarised his views and position in (1930) and in "The Usefulness of Useless Knowledge" (1939, http://library.ias.edu/files/ UsefulnessHarpers.pdf), in which he defended the idea that the university was about intellectual discovery not workplace training.
} 
science (including the loss of legitimacy of the Humboldtian tradition) and the transition to a culture of "performativity", in which the university was seen as an institution whose role is to "produce" wealth or even profit as if it were a "production force". P. Bourdieu (1984/1988) analysed the dynamic transformation of the university environment through such relevant concepts as cultural capital, power and control, and the serious consequences of these on the nature of "homo academicus". J. Habermas (1988) examined the idea of the university from Humboldt to Jaspers and reflected on what remained of it and whether preserving it was at all realistic. He concluded that the traditional university was not dead (although it had been stretched to its limits) but that the conditions under which it was operating were far more complex and its reform was therefore inevitable. Habermas thought "communicative rationality" was crucial to this reform. J. Derrida (2002) sought a "university without condition"; that is, the unconditional academic freedom to ask questions and the right to say what seeking the truth requires. Another (Aristotelean) path to renewing Newman's idea of the university was formulated by A. MacIntyre (2009), which remains true to its essence in developing student thinking and understanding in the broadest sense and at all levels and types of study. In their pursuit of alternatives to the traditional idea, a number of philosophers began (in collaboration with experts from fields such as education, sociology, anthropology and psychology) working on ideas for a new university, for instance, the "postmodern" (Smith \& Webster, 1997), or "virtual" (Robbins \& Webster, 2002), or "ecological" university (Barnett, 2010). The concept of the "multiversity" also appeared in an attempt to transcend the concept of the university per se (Kerr, 2001).

\section{Basic trends in current academic life}

The original and traditional ideas of the university and academic life began changing in the nineteenth century influenced by industrial society and the concept of a specialist education based on science and technology (the concept of the "technical", and later the "economic" university etc.), but did not take on an unprecedented "turbulence" until the latter half of the twentieth century with the rapid development of post-industrial society. This process now seems to be reaching its height in the context of globalization and the so-called information society. Societal processes and "pressures" are feeding into in an unprecedented attack on the identity of academic institutions, and indeed academics. The following processes and powers are involved:

1. globalisation - the global societal context within which universities function is fundamentally changing as a result of changes in the status and functioning of the nationstates that have been the guarantors of the modern university since the Enlightenment (Nelson \& Wei, 2012);

2. Europeanisation - underpins the current developments in universities in Europe, especially through the Bologna Process (Kwiek, 2013), with controversial consequences (Kemp \& Sorensen, 2012);

3. informatisation - is changing the technologies for producing and distributing knowledge in the so-called information society, and this is having an impact on the content of academic work and its significance for society; according to theorists, this trend is supposed to turn the university into the "central institution" of contemporary and future civilisations (Bell, 1973); 
4. neoliberalism - is fundamentally changing the political and ideological context within which universities in the West have been operating since the 1970s; the neoliberal reforms of society in general and education in particular, including universities, have made market principles and financial outcomes central to the way society and human life in all spheres is organised and assessed (Jones, 2012);

5. academic capitalism - capitalist methods of production and social organisation are being applied to the academic sphere in the same manner as in other spheres, especially in material production and commerce (Slaughter \& Leslie, 1997; Slaughter \& Rhodes, 2004).

These are all shaping the characteristics of the current academic situation. The following are the main consequences:

1. marketisation - the tendency to introduce market principles into all areas of the management of academic life and assess its importance, which has led to competition dominating at the expense of cooperation, academic education and research becoming goods and being commodified (Radder, 2010), students becoming the "clients" and "consumers" of university "services"; and the absurd creation of "league tables" of universities and faculties and so forth. (Brown, 2011);

2. corporatisation - the tendency to mould universities and academic life in the shape of corporations as "factories of education/knowledge" (Schrecker, 2010);

3. managerialism - the tendency to colonise university and academic life through management and other principles (from production, trade, banking etc.) (Deem, Hillyard, \& Reed, 2007);

4. economism - the tendency to prioritize economic and financial principles in the administration and assessment of universities and academic life (Collini, 2012);

5. bureaucratism - the tendency to introduce administrative principles into the management of universities and run them like "offices" or state institutions dependent on officials, or bureaucratise academic work with endless numbers of standards, regulations, orders and so forth (Ginsberg, 2011).

\section{Current university crisis: basic problems (Slovakia's case)}

As for Slovakia, one of the key Central-European postcommunist countries, unfortunately, we have not yet critically reflected upon this global development. After 1989, higher education was infected, quite understandably, with euphoria at the ideological liberation of academia, only quickly to be replaced with "massification", as new higher education institutions were established and a higher percentage of students admitted, justified by the need to "catch up" on the developed academic world, which had long been busy solving other problems. This was followed by the implementation of the Bologna Process beginning in 1999, anchored in the higher education act of 2002, which has been repeatedly amended and extended (but not so as to alter its substance). The main protagonist in academic life has become the Accreditation Commission, the government's advisory body, and the neverending process of accrediting and re-accrediting degree courses including "complex"

\footnotetext{
9 Massification, the rise in the number of higher education institutions and students, is the only global trend to have fully caught on in Slovakia (in Britain, it began gradually in the 1970s).
} 
accreditation, promoted as a means of improving the quality of higher education. But which is, in fact, about the "bare" existence and survival of universities, especially the newer ones.

However, it is not only Slovakia's universities and faculties, its departments and subjects, that have had to fight for their existence in recent decades and continue to do so. ${ }^{10}$ Analyses by experts in other countries have for some time now pointed to an unprecedented transformation (Baker \& Wiseman, 2008; Gidley \& Inayatullah, 2000; Solomon \& Solomon, 1993), or an outright crisis (Lucas, 1996; Moberly, 1951; Sommer, 1994), or even the end (disappearance, collapse, disintegration, breakdown or death) of the university (Donoghue, 2008; Readings, 1997; Wilshire, 1990) as we know it and have known it. On the other hand, there are approaches that talk of the necessity of reform (Menand, 2010; Zemsky, 2009) or even revolution (Keller, 1983) in higher education, or conversely of a revolt against the current reforms (Bailey \& Freedman, 2011).

In Slovakia, we can talk of a "critical crisis" in the academic sphere, whose causes have yet to be sufficiently analysed, but, nonetheless, can be attributed to three factors.

First, the Slovak academic tradition is weak and wanting. This is related to the problematic nature of our academic culture. It can be seen, for instance, in the very high level of distrust in society towards academics and academic institutions, but also in the public's ignorance and insufficient knowledge of the specific nature of academic work. People who have never undertaken academic work naturally have no idea of what it involves, nor should they. But that has not stopped them from acting as judges, or even "executioners", who would prefer to eliminate these "parasites feeding on society". So those who perform academic work have to continually demonstrate their "social usefulness", which in Slovakia is viewed through "material outcomes" as a "tangible" product or financial effect. Formal recognition in the shape of once respectable academic qualifications has also resulted in their inflation, or even deflation. The social atmosphere towards academics is either unfavourable or downright hostile, to the extent that the academic occupation, once almost idolised, is now a thankless one (at least for those who approach it with integrity and in seriousness). Moreover, it is no "bed of roses" insofar as the work conditions are concerned.

Second, this negative situation is exacerbated by the media who present academic institutions as society's "servants" and encourage the public to think that "public money must be reciprocated through quality work". But no one is better placed than the academics themselves to say what that quality is and they are the only ones who can achieve it. Quality cannot be guaranteed through accreditations, assessments or measurements, rankings or league tables. At best these are tools that indicate the level. The key to achieving quality can be found only in the work and skills of the academics and the conditions within which they operate. But hardly anyone in Slovakia ever mentions the conditions, or the social atmosphere, in which academics work.

The final and third factor is the managers and academic functionaries who merely "fan the flames" in their inability to find their way around this fast-changing situation. The result is that they do not defend the interests of their academic communities (in the sense, for example, of ensuring they have good work conditions), but perform administrative checks on

${ }^{10}$ This is especially true of the humanities and social sciences as is argued by, for example, $\mathrm{M}$. Nussbaum (2010). 
them in line with criteria that no creative academic would ever set. But then again, the Slovak academic community itself is not comprised of autonomous, decisive "academic citizens" capable of defending their academic rights and freedoms. ${ }^{11}$

There are many acute problems in Slovak academic life, but accreditation and assessment criteria issues do not feature among them, since we can only begin assessing when we have something to assess. First, we have to create, and to do that we have to systematically create the conditions and requirements. The key problems can therefore be identified as:

1. the higher education act - the basic legislative framework comprising the current higher education act and all its amendments contains problematic areas that, instead of creating these conditions (e.g. rigid provisions on guarantors, posts, accreditations), act as a brake on and an obstacle to development;

2. the funding system - based on student numbers, requirements, standards, performance standards, indicators of economic difficulties, student-hours and so on - does not create stimuli nor does it finance the development of higher education;

3. method of governance (management and administration) - it does not have the management arsenal (after which it is called) to ensure the development of higher education; it is overly bureaucratic, formalistic, economistic and politicised and so forth.

These are three aspects to the basic problem, which is the system within which the academic sphere is languishing. It requires a thorough overhaul and complete reconstruction to ensure flexibility and openness to creativity.

\section{Current academic practice}

Within the context of these processes, current academic practice has also become a problem, by which I mean the everyday procedures and practices at the universities. There are three main areas-education, scientific research and management—in which the traditional procedures have been reshaped into "modern" and even "postmodern" ones that come from other spheres and areas of human activity, most frequently industry, business, management and administration. ${ }^{12}$ The key question is whether these new academic practices help and support the universities in fulfilling their missions or whether they in fact hinder and deform.

In education, these practices are associated with the idea, for example, that students are "customers" (the "clients", purchasers or consumers of education services, etc.), or that there is a need for various student assessment questionnaires and surveys, and diverse academic audits. Let us look briefly at the first of these: treating students as customers, and students behaving as customers. This kind of "marketisation" and "commodification" of academic work ignores the key difference between the commercial "producer/consumer" relationship and the pedagogic "teacher/student" relationship. The difference lies in the fact that the

\footnotetext{
${ }^{11}$ In the last twenty years our universities have fallen into a double trap: 1. the state bureaucracy trap, in which communist ideological controls have been replaced by even stricter norm-based controls; 2 . the economic power trap in the form of funding and marketisation based controls.

${ }^{12}$ University life is now undergoing mass "colonisation" through practices, methods, techniques, vocabularies and values adopted from banking or business, for instance (credit, accreditation, guarantors etc.).
} 
customer has "authority" in the marketplace, independently making decisions about what to purchase and consume, while the university student is someone who is still learning; it is the teacher who has the authority, the capacity to know what should be learnt and how. By nature, and in content, the pedagogic relationship simply cannot be a market relationship. Therefore, the practices entering into the educational process from outside are deforming it rather than shaping it in a positive way.

Scientific research requires further practices linked, for instance, to evaluating and measuring results, planning and designing research, collecting evidence and reporting, registering and quantifying publications/citations. Let us look briefly at what the publication statistics tell us about research outputs. It is a practice forced upon the academic world through market practices. It entails reporting the amount produced for consumption per unit of time regardless of the content and nature of the scientific work. However, in essence, this work is neither just a "product" nor a "unit of production"; it is a creative intellectual work, scientific or pedagogic, and the publication of it is merely the form it comes in and the means of communicating it. Focusing on the quantity of publications and citations leads to the "academic market" being flooded with "units" and "indicators", where the aim is generally not scientific gain but something else (where it is to obtain qualifications, grants, career prospects, the fulfilment of standards, etc.). For instance, a citation is similar to the market principle in that it is an "indicator" of the level of "consumption" of academic works on the academic market, which is in itself highly problematic, inappropriate and even absurd at times (in part because in each subject area citation practices differ). In science citations have never been and cannot be a "scientific" measure of the quality of the work (especially not in themselves nor even as the main "indicator"), and so their use as indicators for economists and finance officers is also problematic.

In university management, approaches and techniques are being used that introduce the principle of competition as opposed to the traditional one of collegial collaboration; instead of ensuring the conditions are in place to enable academic work, we have "performance"; instead of controls on resources, we have controls on academic activities. The concept of "performance, for example, has been mechanically transferred from the industrial sphere without respecting the different nature of work in the creative intellectual sphere. This type of "managerialism" simply ignores the nature and content of the work, the results of which cannot be achieved nor assessed in the same way as they are in material production and physical work, through hours of work or other "performance indicators". What we have here is a basic conceptual error, and the task facing philosophy and the social and human sciences is to define the concept of "intellectual production". ${ }^{13}$

\section{Outline of the idea of the creative university}

Although there are many ideas and concepts, models and projects of the university (Christensen \& Eyring, 2011), there is no single one experts can agree on. Some philosophers (working alongside experts in education, sociology, anthropology, psychology, etc.)

\footnotetext{
${ }^{13}$ Work has already begun in this direction (e.g. Peters, Marginson, \& Murphy, 2009; Raunig, 2013).
} 
have begun to develop the ideas of a new university, for example (Barnett, 2010; Kerr, 2001; Robins \& Webster, 2002; Smith \& Webster, 1997). In so doing they are seeking an alternative to the traditional ideas. Whatever it may be, because of its nature, the university has always been an institution which — despite being known as an "ivory tower" isolated and cut off from the rest of society—has stood at the centre of dynamics in modern society. This is particularly true in the current info-techno-culture and civilisation.

It seems that not even the university will escape this major civilisation trend, but that does not mean that it has to become a factory or industry of intellectual and mental production or even a business or enterprise selling intellectual products, or an office controlling intellectual production. Yet, we cannot fail to notice that certain elements typically associated with factories, businesses and offices have already begun filtering into university life. Nonetheless, so long as both the university's mission and essence is intellectual and mental creation as an inseparable and irreplaceable part of society's wealth, and not just material, then the institutional form that determines "the university's existence" will be one that safeguards its "creative spirit" and provides the conditions for intellectual creation as in the motto: "Create and let create!" This is what the idea of the "creative university" is about, based on the fact that creativity is the essence of academic life and work. The goal and mission of the university as an education institution should therefore be to create the conditions in which creativity can be developed in two basic areas of its activities: science and education.

The theory of creativity has been extensively elaborated (Pope, 2005; Runco, 2007), and the following should be nurtured in applying it to university and academic life:

1. the subject - the academic and the academic community as "academic capital", their skills, motivations, values and relationships as being most important in who the university admits (as student or employee), supports through graduation and in their academic career;

2. the process - academic work and practice through which only valuable academic work can emerge;

3. the results - independent creative academic (scientific and pedagogic) work.

Creativity cannot be forced, ordered, commanded or even recorded. It cannot be faked or played at. It can only be stimulated and nurtured. The university of the future, if it exists, should be a free and creative institution that contributes to society's wealth, and cannot be measured in terms of its material effects alone (and nor should that be necessary).

\section{References}

Adorno, T. W. (1959/1998). Theorie der Halbbildung. In T. W. Adorno, Gesammelte Schriften, Band 8 (pp. 93-121). Darmstadt: Wissenschaftliche Buchgesellschaft.

Bailey, M., \& Freedman, D. (Eds.). (2011). The assault on universities. A manifesto for resistence. London: Pluto Press.

Baker, D. P., \& Wiseman, A. W. (Eds.). (2008). The worldwide transformation of higher education. Bingley: JAI Press Inc.

Barnett, R. (2010). Being a university. London and New York: Routledge.

Bell, D. (1973). The coming of postindustrial society. New York: Basic Books.

Bourdieu, P. (1984/1988). Homo academicus. Stanford: Stanford University Press. 
Brown, R. (2011). Higher education and the market. New York and London: Routledge.

Christensen, C. M., \& Eyring, H. J. (2011). The innovative university: Changing the DNA of higher education from the inside out. San Francisco: Jossey-Bass.

Collini, S. (2012). What are universities for? London: Penguin Books.

Deem, R., Hillyard, S., \& Reed, M. (2007). Knowledge, higher education and the new managerialism. Oxford: Oxford University Press.

Delbanco, A. (2012). College: What it was, is, and should be. Princeton and Oxford: Princeton University Press.

Derrida, J. (2002). The future of the profession or the university without condition (thanks to the "Humanities," what could take place tomorrow). In T. Cohen (Ed.), Jacques Derrida and the humanities (pp. 24-57). Cambridge: Cambridge University Press.

Donoghue, F. (2008). The last professors. New York: Fordham University Press.

Fichte, J. G. (1806/1873). Popular works. London: Trubner and Co.

Flexner, A. (1930). Universities: American, English, German. Oxford: Oxford University Press.

Gidley, J., \& Inayatullah, S. (2000). The university in transformation: Global perspectives on the futures of the university. Westport, CT: Praeger.

Ginsberg, B. (2011). The fall of the faculty: The rise of the all-administrative university and why it matters. Oxford: Oxford University Press.

Graham, G. (2008). Universities: The recovery of an idea. Charlottesville, VA: Imprint Academic.

Habermas, J. (1988). Die Idee der Universität - Lernprozesse. In Eigen, M., et al.: Die Idee der Universität: Versuch einer Standortbestimmung (pp. 139-173). Berlin: Springer.

Humboldt, W. von (201). Über die innere und äusere Organisation der höheren wissenschaftlichen Anstalten in Berlin. http://edoc.hu-berlin.de/miscellanies/g-texte-30372/229/PDF/229.pdf

Jaspers, K. (1923/1946). Die Idee der Universität. Berlin: Springer.

Jones, D. S. (2012). Masters of the Universe: Hayek, Friedman, and the birth of neoliberal politics. Princeton, NJ: Princeton University Press.

Keller, G. (1983). Academic strategy: The management revolution in American higher education. Baltimore: The Johns Hopkins University Press.

Kemp, P., \& Sorensen, A. (Eds.). (2012). Politics in education. Berlin: Lit-Verlag.

Kerr, C. (2001). The uses of the university. Harvard: Harvard University Press.

Kwiek, M. (2013). Knowledge production in European universities. Frankfurt am Main: Peter Lang.

Liessmann, K. P. (2006). Theorie der Unbildung. Wien: Zsolnay-Verlag.

Lucas, C., J. (1996). Crisis in the Academy: Rethinking higher education in America. Griffin: St. Martin's Press.

Lyotard, J.-F. (1979/1984). The postmodern condition: A report on knowledge. Minneapolis: University of Minnesota Press.

MacIntyre, A. (2009). The very idea of a university: Aristotle, Newman, and us. British Journal of Educational Studies, 57(4), 347-362.

Menand, L. (2010). The marketplace of ideas: Reform and resistance in the American University. New York: Norton.

Moberly, W. H. (1951). The crisis in the university. London: Macmillan.

Nelson, A. R., \& Wei, I. P. (Eds.). (2012). The global university: Past, present, and future perspectives. London: Palgrave Macmillan.

Newman, J. H. (1852). The idea of university defined and illustrated. http://www.gutenberg.org/ ebooks/24526, accessed 10/15/2013.

Nussbaum, M. (2010). Not for profit. Princeton: Princeton University Press.

Ortega y Gasset, J. (1930/1997). Mission of the university. New Brunswick and London: Transaction Publishers. 
Peters, M. A., Marginson, S., \& Murphy, P. (2009). Creativity and the global knowledge economy. New York: Peter Lang.

Pope, R. (2005). Creativity: Theory, history, practice. New York: Routledge.

Radder, H., (Ed.). (2010). The Commodification of Academic Research. Pittsburgh: University of Pittsburgh Press.

Raunig, G. (2013). Factories of knowledge, industries of creativity. Los Angeles: Semiotext(e).

Readings, B. (1997). The university in ruins. Harvard: Harvard University Press.

Robins, K., \& Webster, F. (Eds.). (2002). The virtual university. Oxford: Oxford University Press.

Runco, M. A. (2007). Creativity: Theories and themes: Research, development, and practice. Burlington. MA: Elsevier.

Schrecker, E. (2010). The lost soul of higher education: Corporatization, the assault on academic freedom, and the end of the American University. New York: New Press.

Slaughter, S., \& Leslie, L. L. (1997). Academic capitalism. Baltimore and London: The Johns Hopkins University Press.

Slaughter, S., \& Rhodes, G. (2004). Academic capitalism and the new economy. Baltimore and London: The Johns Hopkins University Press.

Smith, A., \& Webster, F. (Eds.). (1997). The postmodern university? Buckingham: Open University Press.

Solomon, R., \& Solomon, J. (1993). Up the university: Re-creating higher education in America. Reading, Mass.: Addison-Wesley.

Sommer, J. W. (1994). The academy in crisis: The political economy of higher education. New Brunswick and London: Transaction Publishers.

Washburn, J. (2005). University, inc. New York: Basic Books.

Wilshire, B. (1990). The moral collapse of the university professionalism, purity, and alienation. New York: SUNY Press.

Zemsky, R. (2009). Making reform work: The case for transforming American higher education. Piscataway, NJ: Rutgers University Press.

Institute for Research in Social Communication,

Dúbravská cesta 9 ,

Slovak Academy of Sciences,

84104 Bratislava,

Slovakia

Email: emil.visnovsky@savba.sk 